\title{
The Expansion of Chinese Inter-Insular and Hinterland Trade in Southeast Asia, c. 1400-1850
}

\author{
Kwee Hui Kian
}

Contemporary observers had often remarked on the dominant role of the Chinese as trade intermediaries in Southeast Asia during the late nineteenth and early twentieth centuries (Cameron 1865; Furnivall 1939; Robequain 1944). Although the Europeans were the major importers and exporters in this period, they relied primarily on the Chinese middlemen for the retail and distribution of imported manufactured goods and gathering products for export purposes. This phenomenon motivated the Thai government to impose restrictions on the Chinese commercial and other economic activities from the 1920s (Skinner 1957). Similar discriminatory policies were also implemented by the newlyindependent regimes in Indonesia, the Philippines and Malaysia during the 1950s and 196os. Chief among these was the attempt to remove the Chinese trading presence in the district and rural areas of these countries (Golay 1969).

By targeting against the Chinese, there appears to be two underlying assumptions. Either it was thought that this particular ethnic group possessed superior commercial skills or that they had obtained unfair advantages during the colonial era. These implicit assumptions have inspired various research directions in the immediate post-colonial era. They include the scholarship by Clifford Geertz, Alice Dewey and their colleagues to test if indigenous Southeast Asians such as the Javanese possess entrepreneurial skills and why they have lagged behind alien groups such as the Chinese (Geertz 1960; Dewey 1962). They also continue to inform research discussions about how far guanxi (networking), xinyong (trustworthiness) and other special qualities based on the Confucian creed might explain the superior economic abilities of ethnic Chinese in the late twentieth and twenty-first centuries (Dirlik 1997; Jomo 2003).

Against these assumptions of European sponsorship and Chinese business acumen, this paper argues that the latter's dominant role as trade intermediaries during the colonial period had evolved from developments in the early modern era. It examines how and why the Chinese were becoming prominent players in the inter-insular and hinterland trade of Southeast Asia during the seventeenth and eighteenth centuries. So far little notice has been paid to these commercial sectors compared to the discussion on the maritime trade between East Asia and Southeast Asia, especially the junk shipping between

(C) KWEE HUI KIAN, 2015 | DOI 10.1163/9789004288058_011

This is an open access chapter distributed under the terms of the Creative Commons Attribution-

Noncommercial 3.0 Unported (CC-BY-NC 3.0) License. 
China and the latter region. ${ }^{1}$ Although various recent works are paying greater attention to the links between the entrepôt and secondary ports as well as commercial activities in the more rural and remote regions, they tend to focus on specific locales such as southeastern Sumatra, northern Java and southern Sulawesi. ${ }^{2}$

The following section first maps out the Chinese expansion of inter-insular and hinterland trade in Southeast Asia in the period before the mid-nineteenth century. The second and third sections consider the methods of operation of these traders as well as the developments and characteristics of the regional economy during the seventeenth and eighteenth centuries. The argument is that although the Chinese migrants and their mixed-blood and localized descendants did operate in ways beneficial towards small-scale trading, these features were not peculiar to them. Instead what gave them decisive advantage over other groups of Asian and European commercial agents were the specific characteristics in the development of the Southeast Asian economy during the early modern period. This momentum was then carried over into the nineteenth and early twentieth centuries when they were serving as trade intermediaries especially for the European merchant houses.

\section{The Chinese Trade Expansion in Southeast Asia c. 1400-1850}

The commercial exchange between China and Southeast Asia dates back to the period before Common Era. The earliest carriers of trade were the Austronesian people followed by the Arabs and Indians at the turn of the tenth century. When they started sailing to Southeast Asia during the twelfth and thirteenth centuries, the Chinese primarily conducted trade at the capital towns of Srivijaya and Champa and also subsequently in Melaka from the early fifteenth century. At these entrepôts, Chinese imports including earthenware, metallic manufactures, textiles and tobacco were sold wholesale to the local rulers and major merchants who were in charge of their retail and distribution (Schafer 1967; Christie 1998; K. Hall 2004).

By the early fifteenth century, some Chinese traders began settling down and opened shops in the entrepôts and other flourishing port-towns such as Gresik, Surabaya and Tuban in north Java as well as Palembang and Siam (Reid 1996). If they could not sell all the goods within their short sojourn at the

1 Blusse (1986, 2011); T'ien (1989); Cushman (1993); Reid (1993, 1994); Reid and Fernando (1996); Ishii (1998).

2 Andaya (1993); Knaap (1996); Knaap and Sutherland (2004); Kwee Hui Kian (2006). 
entrepôts, the Chinese junk traders would entrust the remaining commodities to these resident merchants. Besides retailing these goods the Chinese shopkeepers would also buy up products from the locals over several months and sell these to the junk traders and other long-distance merchants when they conducted their annual visits. In areas where commercial opportunities were abundant and the local authorities were welcoming, this settled population became larger. The wealthiest among them also became royal merchants who traded on behalf of the ruler. Some were also appointed as court officials and envoys during tribute missions to China (Reid 1996; Ishii 1998).

Chinese private shipping to Southeast Asia increased exponentially during the late sixteenth century after the Ming emperor lifted the maritime ban in 1567. While $5^{0}$ junks were granted licenses to trade in the region in the 1560 s, the number increased to more than 130 after three decades. Instead of visiting only the entrepôts such as Siam and Melaka, the Chinese junks also started sailing to a range of secondary ports. Since pepper was one of the most coveted Southeast Asian commodities in late imperial China, the latter included especially those located nearest to the pepper-producing regions such as Patani, Brunei, Palembang and Banten (Meilink-Roelofsz 1962; Reid 1993).

From the late sixteenth century resident Chinese traders were not only maintaining shops in the coastal towns but also started itinerant trading. Carrying strings of petty coins and small quantities of imported textiles, earthenware and other trinkets, they peddled into the interior areas to buy products from the agriculturalists. They were especially active in the pepper-cultivation regions in West Java and southeastern Sumatra (Blusse 1986). In Jambi and Palembang, some Chinese traders had also taken up residence in the peppergrowing areas of Kuamang and Tembesi by the early seventeenth century (B. Andaya 1993:54-56, 124-125).

With the arrival of the Europeans in Southeast Asia from the early sixteenth century, the Chinese traders also operated in their enclave port establishments. New to the region, the Iberians and northern Europeans relied on these experienced Asian traders to purchase local commodities for the home market and retail imported items. Within a few years of their establishment the Chinese merchants became dominant players, particularly in Spanish Manila and Dutch Batavia. These two port towns also witnessed a novel development in the history of Chinese migration: While they had previously visited Southeast Asia primarily for commercial reasons, Chinese migrants began arriving at these European settlements not only as traders but also as craftsmen, market gardeners and sugar producers. In Manila the number of Chinese rapidly increased to 20,000 by 1603 and maintained at between 20,000 and 30,000 in the seventeenth century in spite of the Spanish efforts to limit them to a 
maximum of 6,000 (Wickberg 1965:ch.1). As for Batavia the Chinese population grew rapidly from about 300 in 1619 to more than 3,000 in 1627 (Blusse 1986:80-87).

In spite of these developments the Chinese trade and migration before the mid-seventeenth century was relatively limited compared to that in the late seventeenth and eighteenth centuries. By the latter period the Chinese junk shipping had extended its visits beyond major ports to include the coastal towns of Cochinchina, Mekong delta and Siam in the Indochinese peninsula, Cebu and Sulu in the Philippines as well as Ligor (Nakhon Sithammarat), Sangora (Songkhla), Trengganu, Pahang, Johor, Riau, Siak, Aceh, Brunei, Banjarmasin and Makassar in the Melaka Straits and Indonesian archipelago. At this point, they were not only approaching entrepôts and pepper-producing regions but also the coastal ports located nearest to the areas of rice cultivation, tin mines as well as the source regions of maritime products such as sea cucumber and tortoiseshell (Cooke and Li Tana 2004; Knaap and Sutherland 2004; Blusse 2011).

The spectacular expansion of junk shipping was more than matched by that of inter-insular trade conducted by the resident Chinese as they sailed to practically every part of Southeast Asia by the early eighteenth century. Although the South Sulawesians (including Bugis, Makassarese and Mandarese), Malays, Javanese and other groups of traders still assumed a strong presence in regional shipping, the Chinese migrant traders and their mixed-blood and localized descendants (peranakan) were becoming prominent towards the end of the eighteenth century. In Nusa Tenggara for example, the share of Chinese in shipping volume increased from less than $10 \%$ in the 1720 s to hold an equivalent share of one third with the Malays and South Sulawesians by the 1780s (Knaap and Sutherland 2004:61). As for the trade in the Java Sea, although they were not as numerous as the Javanese shippers, the Chinese had become the most important carriers in terms of shipping volume during the $1770 \mathrm{~s}$ (Knaap 1996:64).

Besides inter-insular trade, the Chinese and peranakan Chinese were also able to extend trade into the hinterland as well as the upstream and more rural and remote areas in most parts of Southeast Asia. The following is a snapshot of where they had gained dominance by the late eighteenth century. These could be divided into five categories: The first of these was in the European trading settlements. It is mentioned previously that the Chinese were the most dominant traders in Spanish Manila and Dutch Batavia at the turn of the seventeenth century. As the Dutch East India Company (Vereenigde Oost-Indische Compagnie, voc) set up a string of factories and settlements in the Indonesian archipelago during the seventeenth and eighteenth centuries, the Chinese 
commercial agents followed in their wake. Consisting of between 10 to $20 \%$ of the population, the Chinese and peranakan Chinese dominated the domestic trade of Ambon and Melaka by the mid-seventeenth century and the trend continued into the later centuries (Knaap 1991; Andaya and Andaya 2001:9697). Similar developments could be observed in Padang, and the various port towns along the north coast of Java. ${ }^{3}$

In Makassar, they came to preside over the trade of most of the commodities towards the end of the eighteenth century, a phenomenon which Gerrit Knaap and Heather Sutherland (2004) called the 'Sinification' of private commercial sphere in the port-town. By this time, their other competitors in Makassar were only left with niche markets: The burghers (mostly retired voc administrators) played a significant role merely in the slave export to Batavia while the Malay and South Sulawesian traders were only dominant in the trade of locally-produced textiles, iron knives, coconut products and palm sugar (Knaap and Sutherland 2004, ch. 4; see also ch. 9 in this book).

Besides the European enclave settlements, the Chinese traders were also prominent in polities where Southeast Asian rulers granted them special patronage. One of these places was Palembang. An excerpt from Barbara Andaya (1993:124-125) gives a clear idea the commercial scope open to the Chinese in the locality:

In 1682 there were about thirty Chinese merchants [in the service of the Palembang sultan], four of whom were appointed to supervise pepper deliveries to the [Dutch] Company. ... Below them were four other private merchants who had little to do with pepper and had no influence in the fixing of prices for goods. Twenty-one less prosperous Chinese traders acted as agents for the wealthier merchants in the bazaar and supplied the court with cloth for the interior. At this time there was only one Indian Muslim merchant. Ten years later three of the four men in charge of the ruler's business were still Muslim Chinese...

In Ayutthaya, where many Indian and other foreign merchants used to serve as port-masters (krom tha) and foreign ministers (phrakhlang), they had lost these positions to the Chinese by the early eighteenth century. By the 1720 , they also served as revenue farmers and controlled the tin trade in Ligor and Junk Ceylon (Phuket) (Pombejra 1993; Ariyasajsiskul 2004).

The third area where the Chinese enjoyed commercial dominance was those where Chinese migrants were doing labouring work. It is seen earlier

3 Dobbin (1983); B. Andaya (1993); Nagtegaal (1996); Ota (2006); Kwee Hui Kian (2006). 
that Chinese migrants had been producing sugar in Manila, Batavia and Formosa by the turn of the seventeenth century. From the 1680 os and especially during the eighteenth century, they were migrating to Southeast Asia by the thousands. Many of these Chinese migrants were growing pepper (sometimes together with gambier) in Hatien, Chantaburi, Trat, Brunei, Trengganu, Kelantan, Riau, Mentok, Melaka and Penang. Others undertook copper and zinc mining in North Vietnam and Burma, tin mining in Bangka and parts of west coast of Malay Peninsula as well as gold mining in Pulai (Kelantan) and West Borneo. The Chinese miners and agriculturalists' needs for provisions, tools and other supplies were commonly serviced by the Chinese or peranakan Chinese traders. The latter also marketed the products of these labourers. ${ }^{4}$

The fourth area of Chinese commercial dominance consisted of places which were producing commodities desired in the Chinese market. These included the above-mentioned pepper-producing upstream areas in Jambi, Palembang and Patani but had also extended to regions producing other commodities such as the tin-yielding regions of Junk Ceylon and Ligor. During the seventeenth century, Chinese merchants were buying tin in Ayutthaya after the vassal lords in Junk Ceylon and Ligor delivered the mineral as tribute to the Siamese king. From the early eighteenth century, the Chinese had established direct links by leasing these tin fields from the Siamese rulers and did smelting there while Malays and Thais dug for the tin (Gerini 1905; Ariyasajsiskul 2004; Reid 2011).

Besides tin and pepper, regions yielding the maritime products of seaweed (agar-agar), sea cucumber (trepang) and tortoiseshell (karet) also witnessed a major extension of Chinese trading links. From the late seventeenth century, the Chinese were getting these sea products from the eastern Indonesian archipelago up to the northern Australian seas, primarily by working with Sulawesian and Malay middlemen. The latter would use the capital advanced by the Chinese to liaise with and buy the products from the Bajo sea people, the specialized turtle-catchers and gatherers of seaweed and sea cucumber. By the late eighteenth century, the Chinese would trade directly with the Bajos, exchanging old iron or lengths of cloth in return for the sea products. In other words there was a gradual development from multi-ethnic collaboration to Chinese-dominated trading network (Sutherland 2000, 2011). Similar transitions could be observed in the Chinese acquisition of birds' nests in Java and sandalwood in Timor (Blussé 1991; Hägerdal 2012).

In fact some regions which used to have a strong presence of Chinese traders seemed to have lost them because of diminishing supplies of commodities

4 Chen Chingho (1977); Heidhues (1992, 2003); Vos (1993); Trocki (1997); Andaya and Andaya (2001); Cooke and Li Tana (2004); Nordin (2007); Reid (2011). 
over time. From the late seventeenth century, the Jambi sultan faced increasing poverty due to a decline of the pepper trade. He hence turned to rely on piracy and raiding activities for his income which led to a greater exodus of Chinese traders and further accelerated the commercial decline (B. Andaya 1993:128-129). The fate of the Sulu sultanate was similar. It enjoyed a flourishing trade selling shark's fin, sea cucumber and other maritime products to Chinese merchants during the seventeenth century. By the second half of the eighteenth century, with the depletion of these products in their surrounding seas, the Sulu rulers turned to piracy and slave raiding which drove away most of the trading communities (Warren 2007).

Last but not least, it is also observed that the Chinese became dominant in the rice-bowl regions of Southeast Asia by the eighteenth century. They included central and east Java as well as the Mekong delta, Tonle Sap, Chantaburi and Trat. These spaces drew thousands of Chinese migrants from the 166os. By assuming authority or leasing whole districts in these regions from the local authorities, the Chinese were able to gain control over rice trade. These traders also readily assimilated with the local population, particularly in the Gulf of Siam, and some of the half-Chinese descendants such as Taksin, Mac Thien Tu and Jayadiningrat also became ruling elite in the local polities (Chen Chingho 1977; Nagtegaal 1996; Cooke and Li Tana 2004).

In these regions, the Chinese and peranakan Chinese were able to gain commercial control not only of rice but also other local commodities in the course of the eighteenth century. We know more details about the developments of their trade in central and east Java thanks to the rich voc archives. During the seventeenth century Chinese merchants were already leasing the rights to birds' nests collection and cotton textiles branding from the susuhunan (Javanese ruler) which gave them monopoly over these commodities (Nagtegaal 1996). By the third quarter of the eighteenth century, Chinese traders also came to dominate the trade of the other key products of Java including tobacco, timber and palm sugar, and almost rivaled the Malays in the trade of salt (Knaap and Nagtegaal 1991; Knaap 1996; Kwee Hui Kian 2006). In fact they had effectively penetrated the hinterland economy of Java. For instance, of the 179 passes that the voc had granted for travel to the interior for tobacco trade in the late 1760 s, $90 \%$ were undertaken by the Chinese. Some of these Chinese also resided in Kalibeber, then the most important tobacco market in the interior of central Java (Knaap 1996:98, 130-131).

Because of their commercial control of the production region of basic food provisions, the Chinese also reigned supreme in the inter-insular provisioning trade and became the most important traders in the whole of Southeast Asia. At the turn of the nineteenth century only the hinterland trade of a few regions 
was not dominated by the Chinese. In the Malay Peninsula and Sumatra, trade exchange with the indigenous producers of pepper, tin and gold, as well as with the forest- and sea-dwelling orang asli and orang laut - gatherers of products such as birds' nests, resins, black corals (akar bakar) - was largely serviced by the Acehnese, Malays, Bugis and Minangkabaus (Lee 1995; Andaya and Andaya 2001; Nordin 2007). In Tonkin and Cochinchina, the Vietnamese were the main traders servicing the exchange trade with the Jarai, Rhade, Curu, Roglai, Mnong, Stieng and other uplanders (Li Tana 1998). In these areas, although the Chinese were entering the hinterland trade, these regional traders remained the more dominant commercial intermediaries.

With their trading links extended to most corners of the Southeast Asian region, the Chinese also served as excellent retailers and distributors of imported merchandise. By the seventeenth and eighteenth centuries, besides the Chinese manufactures imported by junk merchants, they were also marketing commodities brought by the Europeans. The latter considered the Chinese so effective in the inter-insular and hinterland trade that they entrusted these intermediary traders with their imported goods such as Indian textiles and opium, either by selling wholesale or granting them the commodities on credit (B. Andaya 1993; Knaap 1996; Knaap and Sutherland 2004).

\section{Methods}

In exploring why the Chinese were able to dominate the inter-insular and hinterland commercial realms in Southeast Asia, some historians have noted that these migrants and their descendants enjoyed some advantages because of the specific ways they conducted business. In her discussion about the success of the Chinese in penetrating the upstream regions of Jambi and Palembang, Barbara Andaya (1993) notes their readiness to integrate with the host society. These traders were adept in picking up languages of the natives and often converted to their religions as well. They also commonly married local women who not only helped take care of their shops but also occasionally accompanied the traders in their trips inland to buy up pepper and sell textiles. Andaya (1993:56) has especially remarked on their skills in reaching the producers and consumers directly:

Using trading methods eminently suited to the local scene, they were essentially small peddlers, being willing to sell by piece rather than lot and offering the buyer a selection of assorted cloth rather than requiring purchase of a twenty-piece pack or corge. 
Moreover they 'displayed a keen sense of changing tastes' among the interior pepper growers and were content with 'slim profit margins' as well as a 'willingness to carry debts for years before pressing for payment' (B. Andaya 1993:56).

Coupled with the itinerant trade and willingness to accept deferred payment was the Chinese readiness to offer goods and money to the producers and gatherers several months prior to the harvest periods and deliveries. This was their standard practice for securing rice, tobacco and other commodities in Central and East Java during the seventeenth and eighteenth centuries (Nagtegaal 1996; Kwee Hui Kian 2006). The Chinese merchants were also prepared to give credit to the Borneo and Sulawesi traders one year in advance for tortoiseshell and birds' nests in eighteenth-century Pasir and Makassar (Knaap and Sutherland 2004:98-102).

Elsewhere I have also highlighted the importance of the Chinese internal networks and social capital. Chinese merchants based in coastal towns customarily gave low-interest loans or advanced goods to other Chinese traders to retail imported goods and gather local products in the smaller towns as well as more rural and isolated regions. Usually they entrusted the loans and goods to traders from the same home village and district or to those with identical surnames as these forms of symbolic capital allowed for social sanction against cheating behaviour and if necessary for appeals of adjudication by the elders (gongqin, zuqin) of these informal organizations. Should the debtor default on the loans or lose the advanced goods it would also be more likely to track down his family members and demand compensation from them. By utilizing these social-cultural mechanisms, a town-based Chinese merchant could extend his commercial links into the hinterland and more remote parts of Southeast Asia (Kwee Hui Kian 2008, 2013).

Although these practices stood them in good stead against other commercial rivals, they were not exclusive to the Chinese. It was observed that other mercantile agents were adopting similar socio-economic strategies as well. The Arab and Indian traders also commonly married local women to aid their commercial ventures in Southeast Asia. In the seventeenth and eighteenth centuries Surat and Coromandel merchants based in Kedah would station their agents in tin-rich Perak to get prior access to the mineral supplies (B. Andaya 1979:67-70). The Bataks, Malays, Acehnese, Minangkabaus, South Sulawesians, Javanese and other regional traders also did itinerant trade into more remote regions and similarly generated advanced credit to secure agricultural products and other commodities (Dobbin 1983; Knaap and Sutherland 2004).

In fact, although they were latecomers in the regional commerce, the Europeans developed these small-scale trading skills over time as well. By the mid-seventeenth century English and Danish vessels would sail along the 
north coast of Java, putting their traders ashore at each harbour to sell textiles and opium to the local market vendors and fetching them upon return after several weeks (Nagtegaal 1996:117-118). During the eighteenth century the Portuguese from Macao who sailed yearly to Goa, Malabar and Coromandel would also call at tin-producing regions on the west coast of Malay Peninsula. They left money or merchandise there on credit, picking up tin on their return journey (B. Andaya 1979:70).

What one edge the Chinese did appear to possess over other Asian traders was their effective use of small denomination currency. Unless goods exchange was conducted in barter, low denomination currency was needed to service what was essentially small-scale trading. In pre-sixteenth century Southeast Asia, local rulers tended to obtain products through tributary deliveries and taxation while most private trade was done through bartering. As the Chinese began trading in the hinterland of Banten during the sixteenth century they introduced pici coins - made of an alloy of base metals such as tin, zinc, lead and/or copper - for exchange with the pepper growers. Since the market value of the metallic content of these coins roughly equated the face value - or what numismatic experts call 'commodity money' - they were acceptable to the local people. By paying the sultan an annual fee, the Chinese kapitan (captain or chief of the local Chinese community) based in the port-town of Banten held the exclusive rights to cast picis (Blussé 1986).

As the Chinese started developing interior trade in Sumatra, Vietnam, Cambodia, Central and East Java as well as other parts of Southeast Asia, they similarly put into circulation petty coins - either imported from China or other parts of Asia or minted in a nearby port-town. ${ }^{5}$ In fact the Chinese were so competent in penetrating local commerce that the Javanese bupatis (lords) and the Jambi and Palembang sultans found it more expedient to get rice, pepper and other products through the Chinese trading links than to exact more tribute and taxation. After the Europeans assumed rule over these various port towns they also relied on the Chinese intermediaries whenever the deliveries from local authorities fell short of the demanded amounts (B. Andaya 1993:5556, Nagtegaal 1996:117-121).

The utilization of petty coins thus gave the Chinese considerable advantage in securing commodities from the producers and gatherers in Southeast Asia. That being said, once these currencies were put into circulation and had gained popularity with the local populace, other traders could use them too. In early modern Southeast Asia, the minting rights were often held by major Chinese merchants based in the port-towns. However all groups of traders - Chinese as

5 Blussé (1986); B. Andaya (1993):80-81, Kwee Hui Kian (2006); Li Tana (2011). 
well as non-Chinese - were using petty coins for goods exchange by the second half of the eighteenth century. ${ }^{6}$

In sum, although the Chinese did enjoy some advantages because of their trading practices and utilization of small denomination coins, these methods alone do not explain why this group was able to reign supreme in the Southeast Asian trading world. Instead the reasons should be located in the particular trajectories in the regional economy during the seventeenth and eighteenth centuries. The following section delineates three developments I consider most crucial to explain the rising Chinese commercial dominance in this period.

\section{Context}

The first was the increasing European demand for Southeast Asian products and their heavy reliance on trade intermediaries to facilitate these acquisitions. The European mercantile interests operating in the region could generally be divided into the various East India companies as well as private traders. The latter included the English country-traders, Dutch burghers, as well as Iberian private traders and their mestizo (people of mixed descent and heritage) counterpart. Although many of the Company administrators and private European traders did come to acquire peddling skills and utilize advanced credit system as noted earlier, they usually proved less proficient than the Asian traders at penetrating upstream and hinterland commerce. The European mercantile agents generally abhorred the haggling practices common among the local people especially when they were dealing with fairly small amounts of commodities. Furthermore their Asian competitors proved more capable at enduring the hardship of hawking into the uplands and were also willing to accept a slimmer profit margin. Oftentimes they would sell imported items at lower prices and purchase local products at higher ones than the European traders. The latter hence preferred to trust out their goods to the Asians for retail and marketing (B. Andaya 1993:55-56).

Moreover the East India companies did not muster sufficient resources to handle all their commercial needs in Asia. This was the case even for the voc which mobilized the biggest number of personnel and ships among the Europeans: Between 1602 and 1796 it sent almost a million Europeans to work in the Asia trade on 4,785 ships, most of them dispatched to Southeast Asia

6 Blussé (1986); Andaya (1993); Knaap and Sutherland (2004); Kwee Hui Kian (2006); Li Tana (2011). 
(Gaastra 2003). Until the outbreak of the Fourth Anglo-Dutch War (1780-1784), it dominated the shipping trade in the ports under its authority. Based on the shipping records, the share of the Dutch company in Makassar's traffic had grown from about 25 to almost $45 \%$ between the 1720 s and 1770 s while it claimed more than half of the total shipping volume from the northern Javanese port towns of Semarang and Surabaya by the 1770s (Knaap and Sutherland 2004:68). But the above was limited mainly to the trade between these major ports with the company's headquarters in Batavia. Even including the private shipping trade of burghers the amount of voc manpower and number of vessels were insufficient to transport provisions and other supplies to all its factories, much less to acquire Southeast Asian products from each of the source regions for the European market.

It was, in other words, necessary for the East India companies and other private traders to work with Asian intermediaries whether for provisioning or to acquire merchandise. Within Southeast Asia it would seem most logical to work with the regional traders. However the European companies often waged wars with the indigenous authorities when they were establishing enclave towns such as Melaka, Batavia, Manila and north coast of Java. Native populations were under explicit orders from their disgruntled rulers not to trade with the Europeans or assist in the acquisition of any supplies and commodities, especially in the immediate aftermath of the armed conflicts (Nagtegaal 1996:115-120; Andaya and Andaya 2001:62).

By comparison foreign Asians were less submissive to the orders of the local sovereigns. Hence in the initial period of takeover of Melaka, the Portuguese worked closely with these Middle Eastern, South Asian and Chinese commercial intermediaries. As for the Spanish, they could not trade directly with Asia under the stipulations of the Treaty of Tordesillas they had signed with the Portuguese in 1494. After setting up their base in Manila, the Spanish authorities mainly relied on Chinese middlemen. Since the main commodities the Spanish coveted in Asia were Chinese porcelain and silks, these commercial agents were singularly well-placed to handle the purchases. Champion of the crusading campaigns in Europe the Spanish were also less tolerant towards the Arab and Indian Muslim merchants and preferred to work with the Chinese.

Meanwhile the VOC and EIC - the two other most dominant European companies in early modern Southeast Asia - found it most expedient to work with the Chinese because the Middle Eastern and South Asian traders were also importing Indian textiles and opium for sales and were therefore their commercial rivals. At times they would prohibit Arab and Indian traders from entering the ports they controlled. Otherwise these European authorities 
would impose high tolls on and/or ban the import of particular types of Indian textiles and other commodities (Laarhoven 1994; Lewis 1995).

Their treatment of the Chinese was vastly different. The Dutch and English commonly 'trusted out' money and cloth to the Chinese who would retail these and gather Southeast Asian commodities on their behalf. The latter included pepper in Sumatra as well as tortoiseshell in the eastern Indonesian archipelago (B. Andaya 1993:55-56; Sutherland 2011). As they were heavily involved in inter-island provisioning especially for the voc, the Chinese traders also came to dominate the rice and salt trade in central and east Java by the turn of the eighteenth century (Nagtegaal 1996; Kwee Hui Kian 2006).

Besides their antagonism with the local ruling elite, the related attempts by the Dutch to establish monopolies over various Southeast Asian commodities to maximize profits further pre-empted the use of regional traders as their commercial intermediaries. In the course of the seventeenth century, the voc conquered the Moluccas and Portuguese Melaka and signed treaties with the local rulers in Makassar, Java, Banten and Palembang, Jambi and Padang. The objective of these military and diplomatic ventures was to form a 'closed sea' to protect a Dutch monopoly over fine spices (clove, nutmeg and mace) and other commodities, and to channel key imports of the voc - Indian textiles and opium - through the company.

In fact once it subjected the north coast of Java and South Sulawesi under its authority, the Dutch administration forbade all regional traders to sail to the Moluccas, especially the Javanese, South Sulawesians and Malays who had been prominent in the spice trade. It also tried to restrict them within the local shipping trade to pre-empt them from establishing links with other European and regional traders in the Sulu Seas, Melaka Straits and west Sumatran coast and from dealing in Indian textiles, opium and other goods over which the voc had tried to establish exclusive sales rights (Knaap and Sutherland 2004:20-29).

These regional traders did not disappear but re-adapted themselves in the face of these restrictions and challenges posed by the Europeans. Nevertheless while they were forced to shift their trading routes and products in their interinsular trade, the Chinese could reign most freely in the Southeast Asian seas in the seventeenth and eighteenth centuries. Even though the shipping volume of the regional traders did not decline and even increased at times, it was inevitable that most of the commercial expansion was absorbed by the Chinese traders and their mixed-blood creole descendants. Although the voc administrators were still wary that the Chinese might engage in spice smuggling, they were seen as the lesser evil compared to the other regional traders. Besides the voc and Dutch burghers, they were the only group of traders allowed to bring 
provisions to Ambon and Banda. Indeed the voc regarded the Chinese rice imports to these spice-producing islands as an indispensable service (Knaap 1996:111-112; Knaap and Sutherland 2004:21).

A second development in the early modern Southeast Asian economy was China's rising needs for regional products. Besides pepper and exotic commodities such as tortoiseshell, resins and sandalwood, the Chinese market had started importing rice, timber and other bulk goods from Southeast Asia since the early eighteenth century, especially from the Gulf of Siam, Luzon and other regions closest to South China (Cushman 1993). Moreover there were significant increases in the demand for particular products such as sea cucumber compared to earlier centuries (Sutherland 2011). Hence the late seventeenth and particularly the eighteenth century saw a peak in the Chinese mercantile activities in Southeast Asia or what Anthony Reid (1997) and Leonard Blussé (1999) call the 'Chinese century'.

In this period the Chinese traders also had to utilize more competitive strategies since tin, pepper and other commodities were also increasingly sought after by the European merchants for their home markets and South Asia. Oftentimes the East India companies were able to use their military strength to gain monopoly rights by signing treaties with local rulers or subjugating the territories under their rule. The Chinese did not have such military strength or backing from their home governments however (Wang Gungwu 1991). What they resorted to was to approach local authorities and obtain similar rights to sole purchase or sales of commodities through the institution of tax farming. In other words they acquired monopolies through monetary payment rather than military force. With these leases, the Chinese tax farmers would then dispatch their agents to purchase and sell goods in the interior. In Palembang, Siam and other polities yielding products in demand in China, the Chinese began dominating revenue farming and extending trade into the hinterland during the late seventeenth and eighteenth centuries (B. Andaya 1993; Pombejra 1993).

Because the Chinese traders had the most freedom to move in the Southeast Asian seas, they were able to conduct a kind of relay shipping trade even for goods coveted by the Europeans. For instance, Chinese merchants based in Palembang could transport tin and pepper to Riau, Trengganu, Hatien, Siam and Cochinchina or those based in the latter ports would sail to Palembang to buy these products. Sometimes the trade was conducted on their own account or on behalf of the rulers and aristocrats or with their partial investments. These commodities would in turn be brought by other Chinese merchants to be brought directly to China or to another port closer to the final market. The European East India companies found it difficult to obstruct this trade without 
jeopardizing diplomatic relationships with the Southeast Asian rulers, especially if the latter had fulfilled their deliveries of the quantity of tin, pepper and other commodities stipulated in the mutual agreements (B. Andaya 1993:188191, 218-222; Cooke and Li Tana 2004).

By the late seventeenth century the increase in the demand for regional products by the European, South Asian and East Asian markets collectively created immense pressure on the production and gathering process in Southeast Asia. Formerly these commodities had been cultivated, mined or collected using a combination of labour from corvee impositions, slavery, wage system as well as market-oriented entrepreneurship. However these systems had a cap limit depending on the availability of population which was especially sparse in places like the island of Borneo and the Malay Peninsula. The frequency of wars also resulted in depopulation in regions such as Cambodia as well as the southern parts of modern-day Vietnam and Thailand during the late seventeenth and eighteenth centuries.

At the turn of the eighteenth century some Chinese entrepreneurs began to explore new ways to tackle the problem of lack of production labour in various parts of Southeast Asia. They invited migrant workers from South China sometimes with the pre-approval of local authorities - to produce rice and pepper around the Gulf of Siam (Chen Chingho 1977; Heidhues 1992). The success of these ventures led to the spread of the use of these migrants for cash crop cultivation and mining activities in many parts of Southeast Asia by the mid-eighteenth century. Largely producing cash crops and mining for minerals in demand by the China market, they fanned out widely to regions where the population was limited or unsubmissive and where local authorities were willing to work with them. An estimated total of about a million Chinese migrants were doing labour work in Southeast Asia by the turn of the nineteenth century. The needs of tools, provisions and other supplies of these production forces and exports of their products were usually served by Chinese mercantile agents, who were also often the ones who had leased lands from the rulers for these production activities and acted as liaisons between the labourers and the local ruling authorities (see for example B. Andaya 1993:218-219).

A third development was the growing commercialization in the Southeast Asian production. In some cases they were connected to the burgeoning demands for regional commodities in the European, South Asian and Chinese markets. For instance, the Minangkabaus, Bantenese and Banjarese progressively converted forests and jungles into agricultural lands for pepper growing in Sumatra, west Java and southeastern Borneo because of the rise in international demands in the seventeenth and eighteenth centuries (Dobbin 1983; Knapen 2001; Ota 2006). Meanwhile other developments of market production 
such as that of Southeast Asian textiles were due to regional economic readjustments. As the Europeans were buying up Indian cloth for the European and other markets, the prices of these commodities became inflated. Unwilling to pay higher prices for the same types of Indian cloth, various Southeast Asian regions including central and eastern Java, Bali, Sumbawa and southern Sulawesi intensified indigenous textile production both for local consumption as well as export to other parts of the archipelago (Knaap and Sutherland 2004; Kwee Hui Kian 2011).

The proliferation of market production generated greater necessities for food imports. By the early eighteenth century the trade in foodstuffs in the rice bowl areas of Southeast Asia - central and east Java as well as Trat, Chantaburi, Mekong delta and Tonle Sap - was in the hands of the Chinese. In the case of Java this was partly because of the sponsorship of the voc which exerted authority over the north coastal region since the late 1670s (Nagtegaal 1996, Kwee Hui Kian 2006). As for the rice production in the southeastern parts of Thailand, Cambodia and Mekong delta, because its main market was South China from the 1720 s and the main exporters were the Chinese, they also began to dominate the domestic rice trade (Cushman 1993; Cooke and Li Tana 2004). Their control of the trade in these rice bowl regions only further entrenched their position as the primary inter-insular provisioning traders.

As they became heavily involved in the intra-regional food trade, the Chinese also developed interests in commodities of commercial value only within Southeast Asia. By the eighteenth century they were dabbling in a very wide range of trade items including slaves, wax, tamarind, areca nuts, terasi (fish paste) and cardamom. Towards the end of the century they were able to rival regional groups and became the most dominant traders in products such as the textiles made in Java, Bali and Sumbawa as well as Javanese tobacco (Knaap 1996; Knaap and Sutherland 2004).

\section{Conclusion}

In sum, it is undeniable that the Chinese adeptness in gaining local knowledge, effective utilization of peddling skills, advanced credit system and petty currencies as well as strategies of networking through their home region ties, family names and other symbolic capital had helped render them strong players in the Southeast Asian commercial world. However it was ultimately the three inter-related economic developments - the Europeans' almost exclusive reliance on the Chinese intermediaries, China's increasing demand for Southeast Asian products as well as commercialization of regional production - that 
enabled the Chinese to emerge as the pre-eminent traders during the seventeenth and eighteenth centuries. This was true both in terms of the trade between China and Southeast Asia and between the various islands within the region. They also enjoyed a significant commercial presence in the interior, upstream and more remote areas of most parts of Southeast Asia, gaining dominance in those of Java, West Borneo, South Vietnam, Cambodia and southeastern Thailand.

It would be wrong to imagine that the Chinese had worked as a single ethnic network though. Operating along the lines of specific loyalties based on common home villages and districts as well as surnames, what was effectively at play was a multitude of cross-cutting and competing organizations. Some of these might form temporary alliances at times but more commonly they were competing against one another, occasionally resorting to violent means, as could be seen in the fightings that broke out between rival Chinese traders and miners in late-eighteenth-century West Borneo and nineteenth-century Malay Peninsula (Kwee Hui Kian 2007, 2013).

Nevertheless, taking the commercial operations of the numerous Chinese networks as a whole, they allowed for the effective retail and marketing of goods imported from other parts of the world as well as the purchase and gathering of Southeast Asian products for export purposes. While they were mainly distributing porcelain, iron products and other Chinese wares through these multiple inter-insular and hinterland commercial channels before the $1600 \mathrm{~s}$, Chinese traders increasingly undertook the retail of the Indian textiles and opium imported by Europeans during the seventeenth and eighteenth centuries. With the industrial take-off and influx of European manufactured goods from the mid-nineteenth century, European merchant houses also took the cue from the predecessors and tapped onto these established Chinese connections instead of building their own distribution networks from scratch. Expanding on the basis of early modern developments, Chinese merchants and traders were able to gain commercial dominance in the whole of Southeast Asia during the colonial period, a momentum that is carried into the postcolonial era as they also come to service the Japanese, American and other multinational companies. 